\title{
Unbinding Genre (Bending Gender): Parody in Goodnight Desdemona (Good Morning Juliet)
}

\author{
Wajih Ayed \\ Head of the Department of English \\ Faculty of Arts and Humanities University of Sousse
}

Tunisia

\begin{abstract}
:
Mourning becomes Shakespeare, perhaps; celebration too. Romeo and Juliet (1597) and Othello (1604) are tragedies of sweeping passion and rash action where love falters and lovers fall. In her 1988 play entitled Goodnight Desdemona (Good Morning Juliet), Ann-Marie MacDonald parodies the two Shakespearean texts and visits the intersections between genre and gender where tragedy modulates into comedy and liminal gender identities fade in and out across permeable genre spaces. The protagonist of the play, Constance Ledbelly, is sucked into the wonderland of her unconscious mind where she outwits her opponents, Iago and Tybalt, and moderates the extremes of her avatars, Desdemona and Juliet. She thus breaks free from her stalking shadow, Night the Professor, and realises that she is the unwitting author of the play. Her unconscious leap onto the stages of mourning becomes a farewell to the night, and a greeting of the morning that becomes the queerness of the postmodernist world-laughing off its past and laughing at its present. The golden pen which Constance finds at the end of her toying with genre, language, and gender is a reward for the author who takes refuge in a world where the fool of court is king of wit, and where the pandemonium of tragedy becomes the playground of parody. The author of this paper studies the alchemy of Constance's change and MacDonald's reconsideration of genre and gender through parody, the postmodern philosopher's stone. He also argues for a politics of identity revisiting the aesthetics of mourning.
\end{abstract}

Key Words: comedy, gender, identity, parody, subversion, tragedy

Cite as: Ayed, W. (2017). Unbinding Genre (Bending Gender): Parody in Goodnight Desdemona (Good Morning Juliet). Arab World English Journal for Translation \& Literary Studies, 1(4). DOI:http://dx.doi.org/10.24093/awejtls/vol1no4.2 